MARTA WIRASZKA

IHS UKSW, Warszawa

\title{
GENEZA ARTYSTYCZNA POMNIKA GROBOWEGO JÓZEFA FRAGETA NA STARYCH POWĄZKACH W WARSZAWIE
}

Grobowiec Józefa Frageta (1797-1867), upamiętniający francuskiego przemysłowca i założyciela pierwszej w Polsce fabryki wyrobów platerowanych, należy do bardziej okazałych pomników nagrobnych, jakie wzniesiono w drugiej połowie XIX w. na warszawskich Starych Powązkach (kw. A, rz. I, m. 9-11).

Grób fabrykanta ozdabia dorycka aedicula - przypominająca formą antyczną kapliczkę $z$ biustem zmarłego na graniastosłupowym postumencie. Popiersie zostało umieszczone pośrodku kolumn ustawionych na narożach prostokątnej podstawy. Kolumny na wzór grecki pozbawione bazy, z entasis i o trzonach pokrytych kanelowaniem dźwigają belkowanie z niskim trójkątnym naczółkiem i dwuspadowym dachem. Zamiast tryglifów i metop znajdują się we fryzie wieńce laurowe. Naroża przyczółka zdobią, podobnie jak podstawę krzyża wieńczącego wierzchołek, renesansowe akroteria o formach wolutowo-palmetowych. Od frontu, na prostokątnej tablicy umieszczonej na architrawie, znajduje się napis: „GRÓB RODZINY FRAGET".

Struktura architektoniczna została w całości wykonana z żeliwa w technice odlewu i ustawiona na kamiennym cokole, który stanowi ostatni najszerszy element trzystopniowej podstawy pomnika. Do niego, centralnie od frontu, przylega wąska prostokątna przybudówka, mieszcząca dostęp do krypty zabezpieczony kamienną tablicą z parą mosiężnych uchwytów. Po jej prawej stronie widoczna jest sygnatura zakładu kamieniarskiego: „W. Tuszyński/ Chłodna 19".

Sygnatura ta miała wpływ na błędną atrybucję nagrobka, którą ze względu na adres zakładu kamieniarskiego, będącego od lat własnością Mantzlów¹, znanej warszawskiej rodziny rzeźbiarzy, przypisano początkowo Józefowi Mantzlowi (1834-1904), wiążąc z jego nazwiskiem wykonanie marmurowego popiersia ${ }^{2}$. Dopiero kwerenda czasopism warszawskich przeprowadzona przez Marię I. Kwiatkowską zweryfikowała ten pogląd. Badaczka ustaliła, że autorem popiersia był Leonard Marconi (1835-1899), syn sztukatora Ferrantego i bratanek znanego architekta Henryka ${ }^{3}$. Na cmentarzu powązkowskim do zidentyfikowanych prac

\footnotetext{
1 M. I. Kwiatkowska, Józef Jan Mantzel - warszawski rzé́biarz i przedsiębiorca, „Rocznik Warszawski” 26/ 1996, s. 47-76.

2 S. Szenic, Cmentarz Powązkowski 1851-1890. Zmarli i ich rodziny, Warszawa 1982, s. 173.

3 M. I. Kwiatkowska, Rzébiarze warszawscy XIX wieku, Warszawa 1995, s. 177; Idem, Warszawski okres twórczości rzeźbiarza Leonarda Marconiego, „Rocznik Warszawski” 28/1998, s. 270.
} 
rzeźbiarza należy także posąg Ukrzyżowanego na grobie Leona Lasockiego (1865, kw. 158, rz. I, m. 1-3) oraz grobowce Ildefonsa Krysińskiego (1871, kw. A, rz. I, m. 17-18) i Józefa Naimskiego (1872, kw. 181, rz. V, m. 1-3).

Popiersie Frageta, wykonane z marmuru karraryjskiego, zostało ukończone na początku stycznia 1869 r. i miało przyozdobić - zgodnie z informacją zamieszczoną w „Kurierze Warszawskim" - istniejący już na cmentarzu powązkowskim pomnik fabrykanta ${ }^{4}$. Wynika $\mathrm{z}$ tego, że projekt mógł być przygotowany w drugiej połowie 1867 r. (Fraget zm. 16 VII 1867) albo na początku roku następnego. Jego montaż musiał nastąpić jeszcze przed zimą, czyli najpóźniej około połowy listopada $1868 \mathrm{r}$.

Zleceniodawcą była zapewne żona Amalia ze Steffenów (zm. 24 IV 1868) ${ }^{5}$, a po jej śmierci realizacją pomnika zajęły się dzieci: synowie Julian Mikołaj i Stefan Desiré oraz córki: Aniela zamężna z Pawłem Kicińskim, Julia zamężna z Teodorem Rogozińskim i Henryetta żona Wacława Chłopickiego ${ }^{6}$. Ostatnia pochowała tu męża i syna, a następnie sama spoczęła w rodzinnym mauzoleum 7 . W grobowcu złożone zostało również ciało syna Julii i Teodora Rogozińskich - Juliana, wicedyrektora fabryki „Wojciechów” w Kamińsku, który zmarł w Warszawie 27 grudnia 1912 r. ${ }^{8}$ Ze śmiercią Juliana Habdank Rogozińskiego należałoby związać przebudowę pomnika, w czasie której powstała obszerna krypta z niską kamienną nadbudówką, wykonana przez zakład kamieniarski przy ul. Chłodnej 19, dawniej należący do Józefa Mantzla, a od około 1904 r. do Władysława Tuszyńskiego9. Wskazuje na to również umieszczenie inskrypcji zmarłego bezpośrednio nad wejściem do krypty.

Pierwotny projekt obejmował zatem tylko część górną obecnego grobowca, wykonaną z żeliwa, która po zmianach wprowadzonych około 1913 r. została podniesiona i ustawiona na kamiennej nadbudówce. Potwierdzeniem takiego rozumowania jest także pierwowzór architektoniczny, jakim się tutaj posłużono. Pomnik Józefa Frageta jest bowiem wierną kopią grobowca Johanna Friedricha Augusta Borsiga (1804-1854), znajdującego się na cmentarzu św. Doroty w Berlinie, którego podstawa ma formę dwustopniowej prostokątnej platformy, ustawionej bezpośrednio na podłożu.

Projektantem mauzoleum Borsiga był berliński architekt, uczeń Schinkla, Johann Heinrich Strack (1805-1880). Wcześniej, w latach 1843-1853, Strack wykonał projekt i nadzorował prace przy budowie mauzoleum Gebharda Leberechta von Blücher (1742-1819), zwycięskiego dowódcy armii pruskiej spod Waterloo i Lipska, w majątku feldmarszałka w Krobielowicach koło Kątów Wrocławskich. Realizacja, ze względów politycznych, miała wymiar wysoce prestiżowy. W powstanie mauzoleum zaangażował się król pruski Fryderyk Wilhelm IV.

\footnotetext{
4 „Kurier Warszawski” 1869, nr 9, s. 3.

5 Pochowana na warszawskim cmentarzu ewangelicko-augsburskim przy ul. Młynarskiej. Do jej pomnika, na zlecenie dzieci, został wykonany portret w płaskorzeźbie przez Bolesława Syrewicza. F. Cengler, Przegląd rzeźbiarski, „Kalendarz Ilustrowany J. Jaworskiego” 1869, s. 43.

6 S. Szenic, dz. cyt., s. 173.

7 Inskrypcje znajdujące się na grobowcu: „Wacław/ Hłopicki/ Pd. Pułkownik W.O.R./ 22 stycznia 1871 r./ w wieku lat 44/ i syn jego/ Roman/ 3 dni życia mający/ stroskana pozostała żona/ tę pamiątkę kładzie” i „Z Fragetów/ Henryetta/ Chłopicka/ zm. 30 marca 1898 r./ w wieku lat 66/ Prosi o westchnienie do Boga”.

8 „Kurier Warszawski” 1912, nr 357, s. 6.

9 Nazwisko tego kamieniarza wymieniane jest w spisie zakładów kamieniarskich po raz pierwszy w $1904 \mathrm{r}$. Tam też została zmieszczona wklejka z reklamą zakładu. W. Tuszyński był tylko najemcą warsztatu należącego wcześniej do Józefa Mantzla. Po jego śmierci posesję przy Chłodnej 19 (nr hip. 927B) zakupił Karol Sommer. Przewodnik po Warszawie na rok 1904, wyd. A. Orłowski, Warszawa 1904, s. 120.
} 
Monarsze zależało na ożywieniu wspomnienia o powszechnie szanowanym bohaterze, zwłaszcza w kontekście przeniesienia i pochówku w 1840 r. zwłok Napoleona w Kościele Inwalidów w Paryżu, którym to uroczystościom Francuzi nadali mocno ostentacyjny patriotyczny charakter. W tej sytuacji nie wypadało, aby pogromca armii Napoleona, nie miał godnego swoich zasług pomnika grobowego. Rozgłos towarzyszący powstaniu tego dzieła mógł mieć z kolei wpływ na wybór Johanna Heinricha Stracka na projektanta monumentu dla Johanna Augusta Borsiga. Z usług tego architekta rodzina Borsigów korzystała później jeszcze dwukrotnie. Według projektów Stracka powstały w Berlinie fabryka maszyn przy Chausseeestrasse (1858-1860) i willa w dzielnicy Moabit w latach 1868-1870 .

Architekt, projektując mauzoleum Borsiga, sięgnął do tradycji rzymskiej architektury, tworząc projekt otwartej budowli z czterema kolumnami w narożach podtrzymującymi belkowanie $\mathrm{z}$ frontonem, który był przetworzeniem antycznej kaplicy z parą kolumn, pomiędzy którymi ustawiana była statua. W 1843 r., przygotowując plany budowli grobowej Blüchera, postąpił podobnie. Wówczas za wzór posłużyło mauzoleum senatora rzymskiego Plautiusa (zm. 79 n.e.), znajdujące się 2 km od wilii Hadriana w Tivoli, przy Via Tiburtina. Pierwowzór rzymski został jednak przez Stracka przekształcony w oparciu o doświadczenia zebrane podczas podróży do Anglii, w którą wybrał się w 1842 r. razem z Friedrichem Augustem Stülerem. Jej celem było obejrzenie znanych osiemnasto- i dziewiętnastowiecznych brytyjskich budowli sepulkralnych. Obaj architekci zwiedzili m.in. mauzoleum filozofa Davida Hume (1711-1776) na cmentarzu Old Calton w Edynburgu, zaprojektowane przez Roberta Adama i ukończone w 1778 r. ${ }^{11}$, które przypomina swym masywnym cylindrycznym kształtem rozwiązanie górnej części mauzoleum Blüchera.

Możliwe, że architekci odwiedzili też inne szkockie miasto - Hamilton, położone $56 \mathrm{~km}$ od Edynburga, w którym rozpoczęto w 1842 r. budowę mauzoleum książąt Hamilton według planów szkockiego architekta Davida Hamiltona (1768-1843) ${ }^{12}$. Mauzoleum Hamiltonów przez swą dwuczęściową strukturę, na którą składa się sześcienna podstawa mieszcząca wejście i cylindryczna wieżowa nadbudowa nakryta kamienną kopułą, najbardziej przypomina śląską realizację autorstwa Stracka ${ }^{13}$.

Podobną zasadę działania można zauważyć, analizując architekturę pomnika berlińskiego, dla którego odniesieniem była rzymska architektura, urzeczywistniona jednakże w obiektach zrealizowanych współcześnie. Zbliżone do berlińskiego monumentu przykłady, pochodzące z pierwszej połowy XIX w., można odnaleźć na europejskich cmentarzach. Najbliższe formą wydają się być te znajdujące się na cmentarzu Père Lachaise w Paryżu. Jednym z nich jest pomnik generała Maksymiliana Sebastiana Foya (1775-1825), wzniesiony przez architekta Léona Vaudoyer (1803-1872), z rzeźbami Davida d'Angers (1788-1856), przedstawiającymi w płaskorzeźbie dwóch geniuszy: elokwencji i wojny oraz trzy sceny z życia generała wykonane tą samą techniką: Przemówienie generała w Izbie Deputowanych, Generał Foy

\footnotetext{
10 J. Kuhn, Das Mausoleum Blüchers in Krieblowitz, „Mitteilungen des Vereins für die Geschichte Berlins“ 88/1992, Heft 4, s. 79-88; C. Wąs, Grobowiec feldmarszałka Blüchera w Krobielowicach, w: Cemetery art-Sztuka cmentarna - L'art. de cimetière. Sympozjum międzynarodowe, październik 1993, red. O. Czerner, Wrocław 1995, s. $269-276$.

11 J. Kuhn, dz. cyt., s. 80 i przypis nr 13.

12 Po śmierci Davida Hamiltona kierował budową aż do jej ukończenia w roku 1858 architekt David Bryce przy współpracy z rzeźbiarzem Alexandrem Handyside Ritchie.

13 Na mauzoleum Hamilton nie zwrócili uwagi Jörg Kuhn ani Cezary Wąs.
} 
w Hiszpanii i Pogrzeb generała. Autorstwa d'Angers jest również statua dowódcy, ukazanego jako retor okryty jedynie płaszczem nałożonym na nagie ciało ${ }^{14}$.

Projekt pomnika został wyłoniony na drodze konkursu rozstrzygniętego w 1826 r. i wzniesiony za pieniądze zebrane dzięki ofiarności społeczeństwa. Jego odsłonięcie nastąpiło w 1831 r., gromadząc, podobnie jak podczas pogrzebu, tłumy na cmentarzu Père Lachaise (Division 28, line 1). Od momentu odsłonięcia grób Foya był najczęściej ilustrowanym i opisywanym pomnikiem nagrobnym w publikacjach poświęconych cmentarzowi paryskiemu. Jego wizerunek zamieścili m.in. Ferdinando Quaglia w Le Père Lachaise ou Recueil de dessins au trait et dens leurs justes proportions des principaux monuments de ce cimetière $(1832)^{15}$, Joseph Marty w Les principaux monuments funèraires du Père-Lachaise, de Montmarte, du Mont-Parnasse et autres cimetières de Paris (1839) ${ }^{16}$ i César Daly w Architecture funéraire contemporaine. Spécimens de tombeaux, chapelles funéraires, mausolées, sarcophages, stéles, pierres tombaies, croix, etc. choisis principalement dans les cimetiéres de Paris (1871) ${ }^{17}$.

Publikacje wymienionych autorów pełniły funkcję wydawnictw wzornikowych i były dobrze znane w Europie architektom i rzeźbiarzom. Przynajmniej jedno z dwóch pierwszych opracowań mogło być nieobce Strackowi. Architekt w swoim projekcie ograniczył się do powtórzenia górnej części mauzoleum Foya, w formie grecko-doryckiej aediculi ustawionej na dwustopniowej podstawie, której surowość złagodził renesansowym detalem, bardziej delikatnym i eleganckim, niż szlachetne, ale nadmiernie przepełnione patosem ozdoby empiru. Statuę generała zastąpił natomiast popiersiem na wysokim prostopadłościennym cokole. Rozwiązanie to mógł zaczerpnąć z opracowania Quaglia, z którego pochodzi litografia pomnika François Chaussier (1746-1828) ${ }^{18}$.

Nagrobek upamiętniający neurologa i profesora anatomii został wzniesiony w $1828 \mathrm{r}$. na Père Lachaise (Division 18, line 1) przez architekta Victora Baltarda (1805-1874). Tak jak w przypadku grobowca Foya był to pomnik w formie grecko-doryckiej aediculi z czterema kolumnami ustawionymi na dość wysokim kilkustopniowym cokole, którego front zdobiły atrybuty lekarskie: laska, kielich i wąż. Powyżej znajdowało się popiersie ustawione na niskim postumencie z inskrypcją zmarłego. Marmurowe popiersie jest jedynym zachowanym do dziś elementem nagrobka. Jego autorem był rzeźbiarz francuski Antoine Allier (1793-1870) ${ }^{19}$.

Twórcą biustu Borsiga odlanego w brązie był Niemiec, Christian Daniel Rauch (17771857). Strack współpracował z nim przy okazji wznoszenia mauzoleum Blüchera w Krobielowicach. Rzeźbiarz wykonał wtedy tondo z popiersiem feldmarszałka okrytego skórą lwa ${ }^{20}$.

14 J. Marty, Les principaux monuments funèraires du Père-Lachaise, de Montmarte, du Mont-Parnasse et autres cimetières de Paris, Paris 1839, s. 132-133.

15 F. Quaglia, Le Père Lachaise ou Recueil de dessins au trait et dens leurs justes proportions des principaux monuments de ce cimetière, Paris 1832, pl. 18.

16 J. Marty, dz. cyt., s. 133.

17 C. Daly, Architecture Funéraire Contemporaine. Spécimens de Tombeaux, Chapelles Funéraires, Mausolées, Sarcophages, Stéles, Pierres Tombaies, Croix, etc. choisis principalement dans les Cimetiéres de Paris, [w:] Bibliothéque de L'architecte par César Daly. Série des Ėtudes D'architecture Contemporaine. Architecture Funéraire Contemporaine. Ducher et Cie, Éditeurs, Paris 1871, section C, pl. 5.

18 F. Quaglia, dz. cyt., pl. 9.

19 Popiersie sygnowane: Allier 1828.

20 J. Kuhn, dz. cyt., s. 81. 
Model gipsowy do pomnika w Berlinie przygotował Rauch w 1855 r. na podstawie maski pośmiertnej ${ }^{21}$. Datowanie grobowca Borsiga można więc przyjąć na lata 1854-1855.

Projekt Stracka okazał się ponadczasowy. Dwa lata po śmierci architekta - 13 maja 1882 r. został odsłonięty pomnik, który wznieśli nad jego grobem na cmentarzu św. Doroty w Berlinie architekci Reinhold Persius i Julius Emmerlich, według projektu bratanka Johanna Heinricha Stracka mł. ${ }^{22}$ Budowla ma formę doryckiej aediculi, częściowo zabudowanej, z parą kolumn od frontu. Przedłużeniem tylnej ściany są filary, tworzące razem z nią prostokątną niszę. Pośrodku aediculi, na wysokim postumencie znajduje się marmurowe popiersie architekta wykonane przez Włocha Aleksandra Calandrelli. Bratanek Starcka nawiązał zatem do znajdującego się na tym samym cmentarzu grobowca Borsiga, nieco go tylko modyfikując.

Natomiast bez żadnych zmian architektura pomnika Borsiga została powtórzona na cmentarzu Hutniczym w Gliwicach w mauzoleum rodziny Brand. W materiałach źródłowych, na które powołuje się monografistka cmentarza, Małgorzata Malanowicz, znajduje się informacja, że pochowany był tu dyrektor huty. Brak inskrypcji, z wyjątkiem jednej: „Bruno Brand/ geb. 22. Januar 1853./ gest. 13. Januar 1890.”, którą odnaleziono na kamieniu grobowym przy remoncie fundamentu pomnika, uniemożliwia weryfikację prawdziwości przekazu. Napisy odnoszące się do pochowanych tu osób znajdowały się, wedle pamięci starszych mieszkańców, na wykonanym z czarnego granitu graniastosłupie ustawionym pomiędzy kolumnami. Podobno dotyczyły jednego mężczyzny i trzech kobiet. Datowanie grobowca jest więc przez to utrudnione ${ }^{23}$.

Trzecim, obecnie niezachowanym, przykładem kopii pomnika Borsiga, był grobowiec Tomasza (1794-1837) i Andrzeja (1795-1841) Evansów na cmentarzu ewangelicko-reformowanym w Warszawie. Bracia, zgodnie z ustaleniem Jadwigi i Eugeniusza Szulców, zostali pochowani w kwaterze F, rząd 3, nr $21^{24}$.

Na podstawie drzeworytu według rysunku Juliana Maszyńskiego zmieszczonego w 1888 r. w „Tygodniku Ilustrowanym” znany jest ogólny wygląd pomnika ${ }^{25}$. Od pierwowzoru różniła go zasadniczo tylko forma i zwieńczenie postumentu ustawionego pomiędzy kolumnami. Zamiast graniastosłupa był to obelisk o przekroju prostokąta i ściętym wierzchołku, na którym stała urna. Inne elementy jak np. akroteria są słabo widoczne z powodu zbyt małych rozmiarów rysunku, który jest jednym z czterdziestu sześciu zamieszczonych na dwóch stronach czasopisma. W opisach cmentarza kalwińskiego, do których dotarłam, tylko raz pojawia się wzmianka mówiąca, że grób Tomasza Evansa należy do nagrobków ozdobniejszych wzniesionych na tym cmentarzu ${ }^{26}$.

Brak informacji i w tym przypadku utrudnia precyzyjnie określenie czasu powstania grobowca. Trudno uznać relację „Kuriera Warszawskiego”, mówiącą, że: Wczoraj odbyte zostało nabożeństwo za zmarłego ś.p. Tomasza Moore Evans, leżacego w grobie familijnym na smętarzu ewangelicko-reformowanym $w$ Warszawie Wa $^{27}$ - za informację odnoszącą się do

\footnotetext{
21 Model gipsowy popiersia Borsiga autorstwa Ch. D. Raucha znajduje się w Deutsches Historisches Muzeum w Berlinie (Inv. Nr.: PL 2000/7). Informacja na stronie muzeum: www.dhm.de [z dn. 4 IV 2015]

22 Vermischtes: Grabdenkmal für Heinrich Strack, „Centralblatt der Bauverwaltung” 2/1882, nr 20, s. 176.

23 M. Malanowicz, Cmentarz Hutniczy w Gliwicach 1808-2008, Gliwice 2008, s. 43.

24 J. i E. Szulc, Cmentarz ewangelicko-reformowany w Warszawie. Zmarli i ich rodziny, Warszawa 1989, s. 71.

25 „Tygodnik Ilustrowany” 12/1888, nr 305, s. 281. [ilustracja oznaczona numerem 21]

26 „Kurier Warszawski” 1898, nr 304, dod. por., s. 3.

27 „Kurier Warszawski” 1840, nr 70, s. 329.
} 
opisanego wcześniej nagrobka. Wzmianka pochodzi bowiem z 11 marca 1840 r. i dotyczy raczej pomnika, który uprzednio upamiętniał miejsce wiecznego spoczynku Evansów. Budowa nowego musiała zatem nastąpić przed opuszczeniem na stałe Warszawy i powrotem do Anglii ostatniego z braci, Alfreda.

Po śmierci Tomasza i Andrzeja, młodsi bracia Alfred i Douglas nadal kierowali fabryką założoną w 1818 r. przez Tomasza w dawnych zabudowaniach kościelnych przy ul. Świętojerskiej. Czynnie też uczestniczyli w życiu zboru, wspierając materialnie jego potrzeby. Pastor Edmund Diehl odnotował ${ }^{28}$, że obaj zaangażowali się w sfinansowanie zakupionego w 1864 r. gruntu pod rozszerzenie cmentarza. Pierwszy na ten cel wniósł składkę Douglas w 1860 r. w wysokości 150 rs. W roku 1866 Alfred wpłacił 2000 rs., która była sumą brakującą do spłaty całkowitej należności. Darowizna zbiegła się z pozwoleniem Namiestnika (3 XI 1866) na przewiezienie zwłok Johna Cockerilla z grobu rodzinnego Evansów do Belgii, z której zmarły w Warszawie w 1840 r. przemysłowiec pochodził ${ }^{29}$, śmiercią Douglasa (1808-1866) i wystąpieniem z firmy Alfreda, którą wykupili, będący z nim współce od roku 1855, Stanisław Lilpop i Wilhelm Rau (1866). Wkrótce po tym Evans wyjechał do Anglii. Rok wcześniej został opublikowany projekt pomnika Borsiga autorstwa Johanna Heinricha Stracka ${ }^{30}$. Fundacja nagrobka mogła zatem nastąpić w drugiej połowie lat sześćdziesiątych XIX w.

Wybór wzorca nie był przypadkowy. Własnością Evansów była fabryka żelaza lanego, produkująca maszyny rolnicze, kuchnie i piecyki do ogrzewania pomieszczeń, naczynia kuchenne, balustrady i kraty różnego kształtu oraz odlewane artystycznie nagrobki, fontanny, medaliony i statuetki ${ }^{31}$. W podobnej branży działał urodzony w $1804 \mathrm{r}$. we Wrocławiu Johann Borsig, nestor berlińskiego przemysłu maszynowego. Założona przez niego w 1837 r. fabryka wyspecjalizowała się w produkcji lokomotyw, które jeździły po torach całej niemal Europy. Na terenie Polski lokomotywy Borsiga woziły towary i pasażerów na linii kolejowej Warszawa - Wiedeń. Zwiększające się z każdym dniem zamówienia, wskazały potrzebę pomnożenia liczby robotników, w miejsce zaś pierwiastkowo skleconych szop drewnianych, stanęty odpowiednie potrzebie i estetycznemu smakowi warsztaty ${ }^{32}$. W roku 1870 zakłady Borsiga zatrudniały blisko 4 tys. robotników. Fabryka produkowała ponadto urządzenia parowe do cukrowni, gorzelni, przędzalni, młynów, itp. W celu zabezpieczenia dostaw surowca, sprowadzanego dotychczas z Anglii i Belgii, Borsig zakupił na Śląsku kopalnie żelaza i wzniósł w ich sąsiedztwie dwadzieścia wielkich pieców hutniczych ${ }^{33}$. Przy nich powstawały osiedla dla pracowników koncernu (np. w Zabrzu 1863-1871). Wedle opinii wyrażonej w „Kalendarzu Ilustrowanym na rok 1870” podsumowującej dokonania przemysłowca: August Borsig byt tym dla przemystu maszynowego w Prusach, czym dla przemystu maszynowego belgijskiego byt John Cockerill ${ }^{34}$. Parafrazując ten cytat, można

28 E. Diehl, Wiadomości historyczne o cmentarzu ewangelicko-reformowanym $w$ Warszawie, Warszawa 1893, s. 32 i 45 .

29 John Cockerill zmarł w drodze powrotnej z Rosji do Belgii.

30 Litografię wg. projektu J. H. Stracka wykonał W. Loeillot z Berlina. „Architektonisches Skizzenbuch” 1865, Heft 1 (72), Blatt 3 .

31 „Kurier Warszawski” 1822, nr 248, s. 1.

32 A. Grąbczewski, Zakłady Borsiga w Berlinie, „Gazeta Przemysłowo-Rzemieślnicza” 1872, nr 24, s. 187.

33 Tamże, s. 188.

34 Zaktady Borsig'a w Berlinie, „Kalendarz Ilustrowany J. Jaworskiego” 1870, s. 51. 
powiedzieć, że Johann August Borsig był tym dla przemysłu maszynowego w Prusach, czym dla Królestwa Polskiego była fabryka Braci Evans.

Ta sama branża przemysłowa połączyła dyrektora Huty Gliwickiej - Branda z Borsigiem właścicielem zakładów maszynowych w Berlinie. Huta w Gliwicach została założona w 1796 r. z inicjatywy hr. Fryderyka Redena, dwa lata później otwarto Królewską Odlewnię Żeliwa. Fabryka od początku specjalizowała się w odlewach artystycznych i zbrojeniowych, współpracując z podobnymi zakładami w Ozimku, Berlinie i Seyn. Na cmentarzu otwartym przez Zarząd Huty Gliwickiej w 1808 r. chowani byli pracownicy huty i ich rodziny, którzy zarazem byli mieszkańcami dzielnicy hutniczej ${ }^{35}$.

Produkcją galanteryjnych wyrobów metalowych zajmowała się też fabryka założona przez Józefa Frageta, Francuza przybyłego do Polski w 1824 r., świeżo po ukończonych studiach politechnicznych w Paryżu i Berlinie, na zaproszenie ówczesnego ministra spraw wewnętrznych Tadeusza Mostowskiego.

Pierwszy jego zakład urządzony był w wynajmowanej oficynie dawnego pałacu Łubieńskich, przy ul. Królewskiej. W 1844 r. został przeniesiony do nowowybudowanych obszernych pomieszczeń przy ul. Elektoralnej 16 (nr hip. 753), którą to posesję razem z kamienicą dawniej należącą do Jakuba Hempla zakupił na własność. Stale wprowadzał ulepszenia i nowe sposoby fabrykacji. W 1848 r. zainstalował maszynę do wyrabiania sztućców stołowych, którą następnie udoskonalił w 1859 r., kupując od Austriaków patent ulepszający ich produkcję. Dzięki temu mógł dziennie produkować 150 tuzinów. Jako pierwszy w Warszawie otworzył laboratorium galwaniczne do posrebrzania i złocenia swoich wyrobów. Fabryka Frageta pokrywała zapotrzebowanie nie tylko rynku krajowego, ale sprzedawała również swoje wyroby za granicą, przede wszystkim na obszarze cesarstwa rosyjskiego, posiadając własne magazyny w Petersburgu, Moskwie, Charkowie, Kijowie, Odessie, Rydze i Tyflisie. W roku śmierci fabrykanta zakład zatrudniał 239 pracowników, a majątek zmarłego obliczono na 316 tys. rs. Po śmierci Józefa Frageta kierowanie przedsiębiorstwem przejął jego syn, Julian (1841-1906), który znacznie rozszerzył rynki zbytu. Zakład przetrwał do roku 1939 pod niezmienioną nazwą Fabryki Wyrobów Srebrnych i Platerowanych Józefa Frageta ${ }^{36}$.

Wszystkie opisane grobowce, z wyjątkiem pomnika wzniesionego nad grobem architekta Johanna Friedricha Stracka, upamiętniały osoby związane z przemysłem metalowym. Skopiowanie pomnika grobowego znanego i powszechnie szanowanego przemysłowca Johanna Augusta Borsiga, który stanął w Berlinie, mieście, z którym każda z wymienionych osób miała bezpośrednią styczność i którego wizerunek został spopularyzowany wydawnictwem albumowym w 1865 r., zaowocowało serią podobnych monumentów. W tym przypadku wybór wzorca nie podyktowało jedynie piękno i szlachetność architektury, lecz przede wszystkim osoba zmarłego, ciesząca się dużym poważaniem w środowisku przemysłowców branży metalowej.

Odmienność pomnika Józefa Frageta polega na zastosowaniu żeliwa jako podstawowego materiału budowlanego. Jest to cecha wyróżniająca go od innych przykładów, które wykonano z kamienia. Niestety nie zachował się żaden przekaz informujący o zakładzie, w którym

35 M. Malanowska, dz. cyt., s. 7-12.

36 S. Szenic, dz. cyt., s. 172-173; „Kurier Warszawski” 1867, nr 177, s. 1110; S. Nelkenowa, Fraget Józef (17971867), w: Polski Stownik Biograficzny, red. W. Konopczyński, t. 7, Wrocław 1948, s. 74; J. Zieliński, Atlas dawnej architektury ulic i placów Warszawy, t. 3, Warszawa 1996, s. 86-87. 
dokonano odlewu. Można jedynie domniemywać, że mogła nim być Fabryka Budowy Maszyn i Odlewów „Evans, Lilpop et Comp.”, przekształcona w 1873 r. w Towarzystwo Akcyjne „Lilpop, Rau i Loewenstein”.

Przedsiębiorstwo od początku swojego istnienia trudniło się odlewem żeliwnych nagrobków. Szczególnie jeden przykład wydaje mi się niezmiernie ważny dla potrzeb niniejszego tematu. Chodzi mianowicie o pomnik Stanisława Lilpopa (1817-1866) znajdujący się na Starych Powązkach w Warszawie (kw. B, rz. I-II, m. 4-8). Nad grobem przemysłowca stanął nagrobek w formie żeliwnej wieży - kapliczki (wys. ok. 12 m), ,podług rysunku Pana Marconiego" ${ }^{37}$, z popiersiem zmarłego autorstwa Leona Molatyńskiego (1825-1898) odlanym w metalu w fabryce Filleborna na Lesznie ${ }^{38}$. Zgodnie z ustaleniem Tadeusza Rudkowskiego, zamówienia dokonała żona Joanna z Petzoldów, która zastrzegła, że ze względu na charakter działalności zmarłego winna to być konstrukcja żelazna ${ }^{39}$. Prasa warszawska odnotowała jeszcze, że odlewu pomnika dokonano w fabryce Lilpop i Rau. Wcześniej, w tej samej fabryce, identyczny w formie pomnik został wykonany pomiędzy 1856 a 1859 r., z przeznaczeniem na grób Tadeusza Rejtana w Lachowiczach ${ }^{40}$.

Pomnik Lilpopa został ustawiony na Powązkach w 1867 r. i poświęcony 15 czerwca następnego roku ${ }^{41}$. Rok później stanął na cmentarzu grobowiec Frageta. Zbliżony czas powstania, bliskie sąsiedztwo i rozmiary obu nagrobków podsuwają myśl, że także pomnik Frageta mógł być odlany w tym samym zakładzie.

37 „Kurier Warszawski” 1867, nr 75, s. 453. Projektantem mógł być albo architekt Leandro Jan Ludwik (18341919), syn Henryka, albo rzeźbiarz i architekt Leonard (1835-1899), syn Ferrantego, który był bratem Henryka.

38 „Kurier Warszawski” 1867, nr 157, s. 984-985, M. I. Kwiatkowska, Rzeźbiarze..., dz. cyt., s. 112. Cyzelowanie popiersia wykonał pracownik fabryki, Karol Tachelicz.

39 Dalej autor sugeruje, że odlewu dokonała warszawska fabryka Karola Mintera. T. M. Rudkowski, Cmentarz Powazkowski w Warszawie. Panteon polski, wyd. 2, Wrocław 2014, s. 247.

40 Pomnik ostatecznie stanął w Krakowie, na skwerze u zbiegu ulic Basztowej, Dunajewskiego i Garbarskiej. Jego oficjalne odsłonięcie nastąpiło w czerwcu 1890 r. Zarówno on jak i pomnik Lilpopa swą formą architektoniczną przypominają najbardziej, zdaniem Elżbiety Lang, pomnik berliński wg projektu Schinkla wzniesiony w latach 1817-1821 ku czci żołnierzy poległych w wojnach napoleońskich. E. Lang, Z dziejów krakowskich Plant-pomnik Tadeusza Rejtana, „Krzysztofory. Zeszyty Naukowe Muzeum Historycznego Miasta Krakowa” 2008, nr 26, s. 159172.

41 „Kurier Warszawski” 1867, nr 75, dz. cyt., s. 453, „Kurier Warszawski” 1867, nr 157, dz. cyt., s. 984-985, „Kurier Warszawski” 1868, nr 121, s. 4-5, „Kurier Warszawski” 1868, nr 127, s. 2, „Kurier Warszawski” 1868, nr 129, s. 2. 


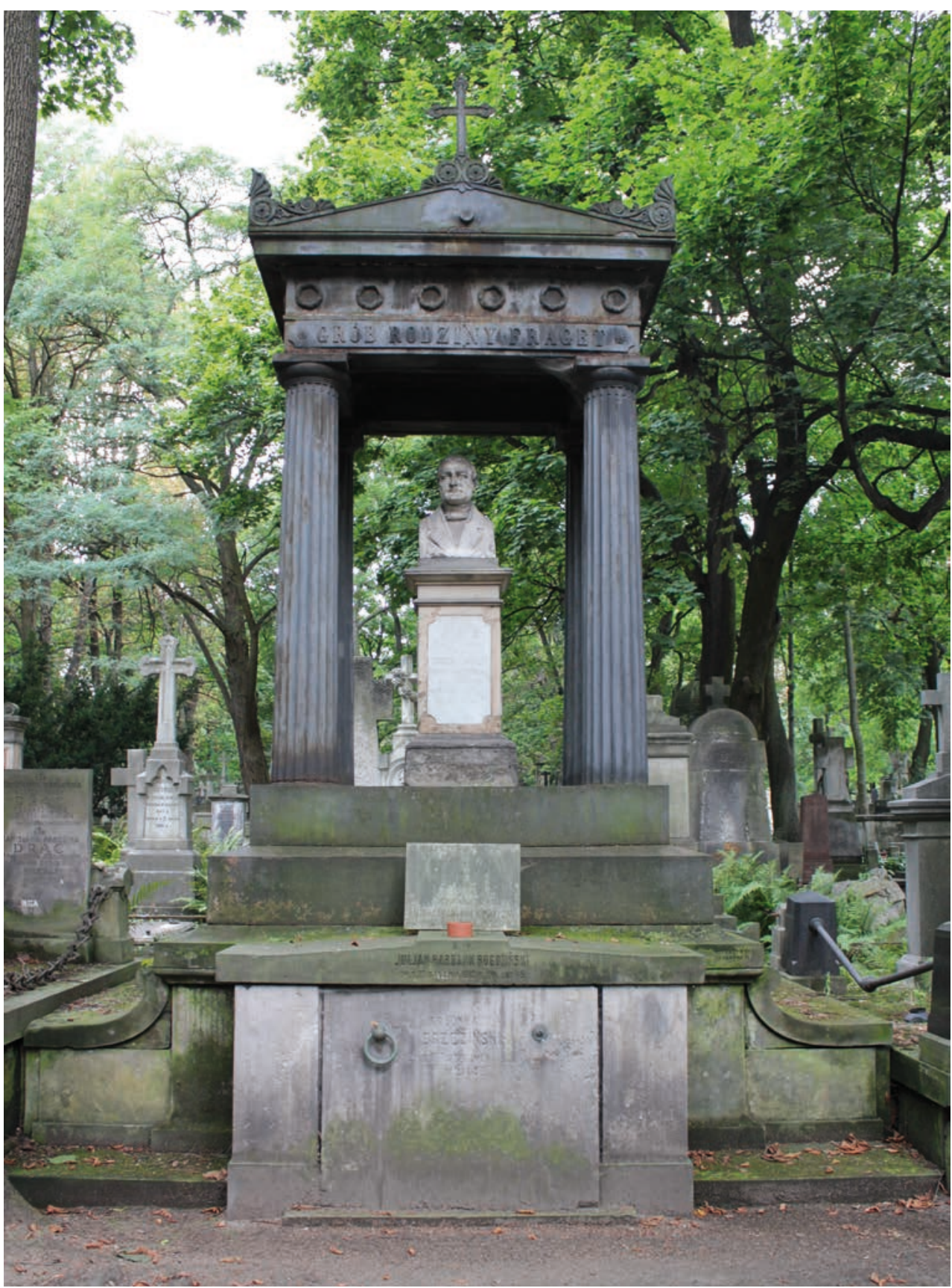

il. 1. Mauzoleum J. Frageta na Powązkach w Warszawie. Fot. M. Wiraszka 


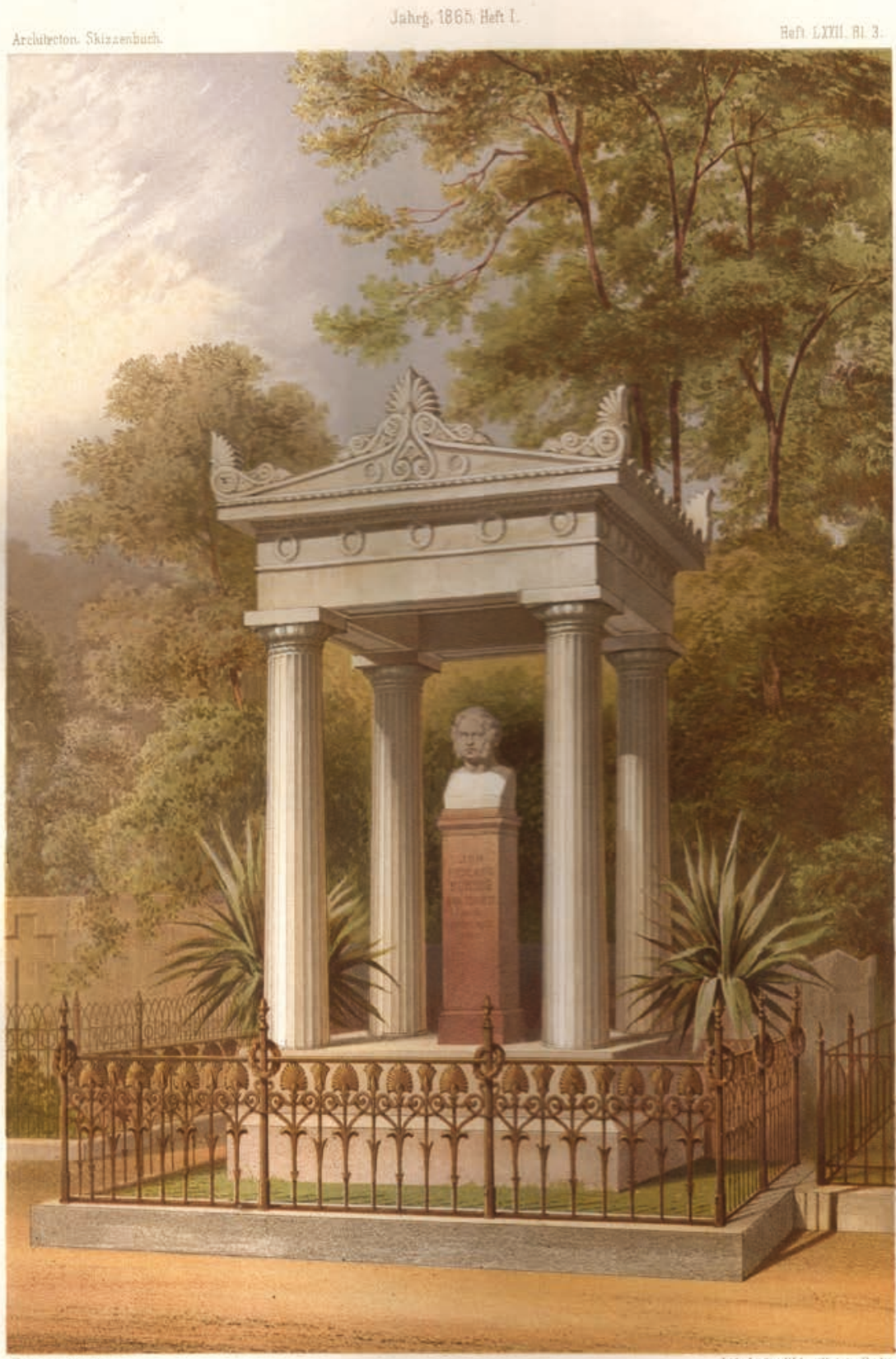

I F A Borsig̨s Erbbegiräbniss

auf dem Dorotheenstädtischen Kirchhofe bei Berlin.

il. 2. Pomnik J. A. Borsiga na cmentarzu św. Doroty w Berlinie, 1865, lit. W. Leoillot wg. proj. arch. J. H. Stracka 


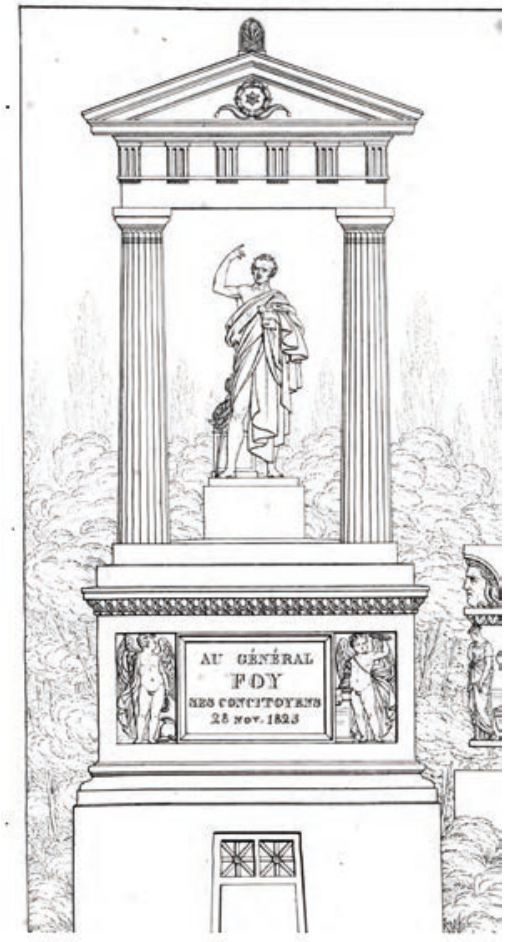

il. 3. Pomnik M. S. Foy na Pere Lachaise w Paryżu, 1832, lit. F. Quaglia



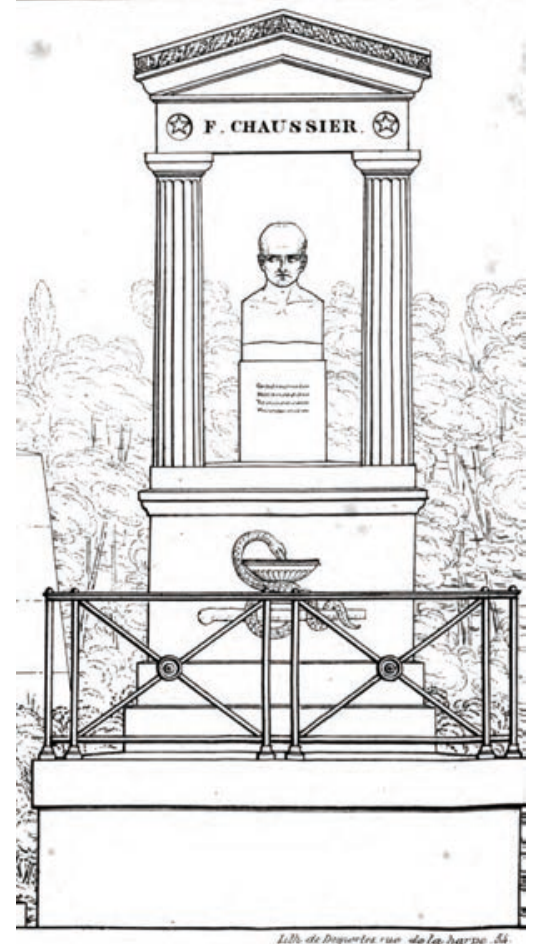

il. 4. Pomnik F. Chaussier na Pere Lachaise w Paryżu, 1832, lit. F. Quaglia il. 5. Mauzoleum T. Evansa na cmentarzu ewangelicko-reformowanym w Warszawie, 1888, rys. J. Maszyński 


\section{Artistic genesis of the history of the mausoleum of Józef Fraget at Old Powązki Cementary in Warsaw Summary}

Neoclassical mausoleum of Józef Fraget (1797-1867) commemorating a French industrial entrepreneur and the founder of the first factory of clad goods in Poland was constructed at Old Powązki Cemetery in Warsaw between 1867 and 1869 (quarter A, row I). The author of the torso is Leonard Marconi, and the mold is believed to have been made by the "Lilpop, Rau i Loewenstein" factory in Warsaw. The original project embraced only the top, cast iron part of the tomb in the form of Doric aedicule with entablature and triangular pediment as well as the marble torso placed on prism pedestal located among four columns. The bottom, stone part, was executed later, approximately in 1913 in Władysław Tuszyński stone enterprise.

The Mausoleum of Fraget is a replica of the monument situated in Berlin at St. Dorothy's Cemetery commemorating Johann August Borsig (1804-1854), the owner of the

well-established metal factory in Europe. Its designer was an architect from Berlin, an apprentice of Schinkl, Johann Heinrich Strack, and the maker of the bronze torso mold was a sculptor Christian Daniel Rauch. Three other mausoleums originated from the same model: the Brand family mausoleum at the Metallurgical Cemetery in Gliwice, (between 1865 and 1890), Tomas Evans mausoleum at the Evangelical Reformed Cemetery in Warsaw (second half of the 60s. the XIX century, currently non-existent) and in its slightly modified form, the tomb of the architect J. H. Strack at the St Dorothy's Cemetery in Berlin (1880-1882).

All the above-mentioned mausoleums except the monument decorating the tomb of the architect Strack, commemorated personalities from metallurgical industry. The particularity of the mausoleum of Józef Fraget consists in the use of cast iron as the main constructing element. It is a distinctive feature differing the mausoleum in question from the remaining exemplary monuments made of stone.

Translated by Monika Kolenda

Keywords: mausoleum, cemetery, neoclassicism, Powązki, Warsaw, Berlin, Gliwice, Józef Fraget, Leonard Marconi, Johann August Borsig, Johann Heinrich Strack, Christian Daniel Rauch, Thomas Evans, Family Brand

Nota o Autorze: dr Marta Wiraszka - wykładowca historii architektury w Instytucie Historii Sztuki UKSW w Warszawie. Zajmuje się zagadnieniami z historii urbanistyki i architektury XIX i pierwszej połowy XX w., w szczególności byłych kresów południowo-wschodnich Rzeczypospolitej oraz kaplic i mauzoleów budowanych na polskich cmentarzach wyznań chrześcijańskich 